\title{
Study on the Development of Sports Cultural Creativity Industry
}

\author{
Guoquan Zhang ${ }^{1, a}$, Ying Zhang ${ }^{2, b}$ \\ ${ }^{1}$ Department of Physical Education, Bohai University, Jinzhou, 121013, China \\ ${ }^{2}$ College of Education and Sports, Bohai University, Jinzhou, 121013, China \\ a673722120@qq.com, b47086132@qq.com
}

Keywords: economic globalization; sports culture; creativity industry; national economic development

\begin{abstract}
With the development of China's economy and the trend of economic globalization, sports culture has increasingly become a representative of a country excellent culture. Sports cultural creativity industry as one important part of sports culture is also showing a good trend in China's development. Firstly, the significance and meaning of sports cultural creativity industry is introduced; then, in-depth analyzing the problems existing in the development of sports cultural creativity industry; and finally, specific measures and countermeasures are put forward for the existing problems in development. Although China's sports cultural creativity industry is just starting, sports as the background, culture as resources and creativity as thinking promote the development of sports cultural creativity industry as another driving source of sports industry and even the national economy development.
\end{abstract}

\section{Introduction}

Sports cultural creativity industry is the industrial aggregation deep integrated by sports, culture and creativity. In twenty-first century, with the coming of knowledge economy era and the progress of social economy, sport industry is developing rapidly, which becomes one of the current sunrise industries had broad development prospects. Culture is the gene to identify a nation, and creativity is the driving force of a country and region to continue developing. As global economic integration accelerates, creativity industries are rising at home and abroad, which has become an important trend in the economy development of major cities, it embodies the perfect combination of science and technology, culture and commerce. Currently, the economic benefit of creativity industries in the world can create over $\$ 22$ billion every day, and showing annual growth of $5 \%$ per year, this ratio respective stands at $14 \%$ and $12 \%$ in the United States and Britain, creativity industries are setting off a huge wave of economy in the world and affecting the development of the world economy gradually [1]. Sports cultural creativity industry is the emerging industry integrated by creativity and sports culture, which has become a new economic growth point of the sports industry and has good market prospects and long-term development potential. It concentrates on cultural character of close to people's lives reflected by innovation, and it is an excellent sports culture acted on industrial economy development to improve the quality of life [2].

\section{The Meaning of Sports Cultural Creativity Industry}

The domestic experts and scholars have different opinions about the meaning of sports cultural creativity industry, there is no unified view. However, the description for sports cultural creativity industry is similar. Du Wen and Yang Aihua define the domestic sports cultural creativity industry in "Inheriting 'People's Olympics' and developing sports cultural creativity industry" is: the sports culture as the core, the sports cultural creativity as a tool, incorporating culture, economy and social factors, developing in the context of globalization consumer and globalization culture, it respects innovation and individual creativity with intellectual property, and emphasizes the new ideas and practices of sports culture on economic promotion. The definition given by Liu Muyu in "Development Theory and Practical Exploration of Beijing Cultural Creativity Industry" is: "creation and innovation as a fundamental mean, culture content and creativity results as core 
values, intellectual property achievement or consumption as transaction characteristics, cultural creativity industry provides cultural experiences' industry clusters with an inner link for the public." [3]. Sports cultural creativity as a mean, sports culture as the core, sports cultural creativity industry condenses personal wisdom and creativity, the sum of industrialization activities can be formed through the market operation and science and technology supporting. The core of sports creativity industry is the innovation development of sports culture, which is putting the creative thinking into all aspects of the sports industry, such as research, production and sale and so on, and converting intangible assets into sports cultural products with intellectual property and practical values, and it is the innovation, creation, maintenance and development for sports culture. Sports cultural creativity industry is part of the culture industry, it has the general characteristics of cultural industry development, as a member of the cultural industry, it also has its own characteristics and development mode.

(1) Sports cultural creativity industry has the characteristic of high knowledge. First, sports cultural creativity industry shows the characteristics of high educated and intelligentialize, the core of industry is culture and creative ideas, which is the specific product of man's knowledge, wisdom and inspiration. When it is combined with information technology and other high-tech industries, the present high knowledge becomes more apparent.

(2) Sports cultural creativity industry has the characteristic of high value-added. Cultural creativity industry is in the value chain of high-end part of technological innovation and $R \& D$ industry, which is a high value-added industry [4]. It is mainly manifests that creative ideas give concept value to commodity, market value of commodity is determined by the concept value of the commodity, the concept value is generated because of creative ideas, and it is an additional culture concept. Commodities with the same value and technical quality, its economic values are not only improved due to the improvements of use function and technical quality, but also added creativity personalities. Therefore, the higher creativity quality is easy to have higher added-value, and creativity is the process to create values.

(3) Sports cultural creativity industry has the characteristic of high integration. As an emerging culture industry, it is the product integrated by economy, culture and science and technology, which has high integration, strong permeability and radiation. Sports cultural creativity industry has a strong dependence with associated industries, while the rapid development of sports cultural creativity industry has also created favorable conditions for the development of associated industries.

Sports cultural creativity industry not only belongs to sports industry, but also cultural creativity industry, after sports technology, sports economy and sports culture are infiltrating, combining, blending and sublimating, it is tangible carrier of new thinking, new technology, new content with high economy values [5], the specific meaning picture shows in Fig. 1.

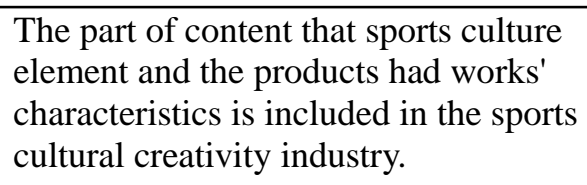

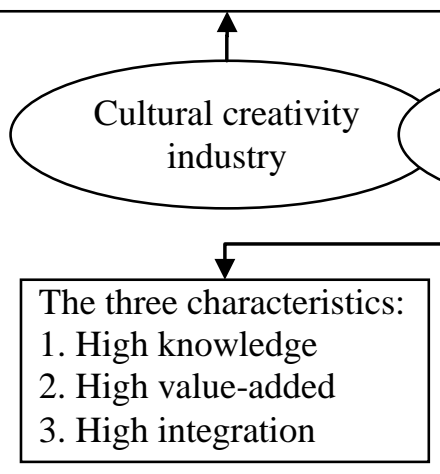

The part of content that creative conception and design is developed and used by intellectual property is included in the sports cultural creativity industry.

Fig. 1. The meaning picture of sports culture creativity industry 


\section{The Problems Existing in the Development of Sports Cultural Creativity Industry}

Along with the strong propulsion of "cultural province" strategy, sports cultural creativity industry in Liaoning Province has made considerable progress, with the emergence of various creativity industries, sports cultural creativity industry is becoming a new growth point of sports industry development, but it has some deficiencies that need to find a fundamental mean to solve them in development.

(1) Development awareness of sports cultural creativity industry is lagging behind. Sports cultural creativity industry as an emerging industry of knowledge-intensive, not only people have little knowledge of it, but also the relevant government departments know little about of its meaning and characteristics. They often confuse sports cultural creativity industry with sports industry, and there is no clear definition for the meaning of sports cultural creativity industry, basic structure framework, organization form and development mode, the theoretical research in these aspects is not enough. Its huge role to promote economy has not been recognized by the majority of people, and even those who are thinking behind still deny that culture is an economic resource actually. The consciousness of lagging behind can become an obstacle to the development of sports cultural creativity industry.

(2) Sports cultural creativity industry lacks of combination strength with other related industries. Sports industry has a strong overall effect and promoting function, the development of sports cultural creativity industry is generated by the combination of sports industry and culture, tourism and electronic information. Taking Olympic Games as an example to illustrate its influence for the tertiary industry, the specific is shown in Table 1. 
Table 1. Effect of Beijing Olympic Games on the tertiary industry growth

\begin{tabular}{llccc}
\hline No Department name & $\begin{array}{c}\text { Annual growth was } \\
\text { achieved between } \\
2001 \text { to } 2007\end{array}$ & $\begin{array}{c}\text { The percent of growth rate is } \\
\text { rather than Tenth Five-Year Plan } \\
\text { affected by Olympic Games }\end{array}$ & $\begin{array}{c}\text { The proportion of } \\
\text { Beijing GDP was } \\
\text { accounted in 2008 }\end{array}$ \\
\hline 1 Commerce & $12.3 \%$ & 2.1 & $7.5 \%$ \\
\hline 2 & Culture industry & $11.2 \%$ & 0.8 & $5.5 \%$ \\
\hline 3 & Sports industry & $11.6 \%$ & 1.0 & $0.4 \%$ \\
\hline 4 & Warehousing & $10.9 \%$ & 1.7 & $1.0 \%$ \\
\hline 5 & Catering industry & $12.5 \%$ & 1.0 & $0.8 \%$ \\
\hline 6 & Social services & $13.4 \%$ & 0.5 & $9.0 \%$ \\
\hline 7 & Finance and insurance & $12.5 \%$ & 0.5 & $11.2 \%$ \\
\hline 8 & Postal service & $13.8 \%$ & 0.6 & $4.4 \%$ \\
\hline 9 & Real estate & $16.3 \%$ & 0.4 & $6.0 \%$ \\
\hline
\end{tabular}

This shows that the Olympics Games directly increases the proportion of tertiary industry in the national economy to guide industrial restructuring. To this end, we should summarize the successful experience of the Beijing Olympic Games to scale sports cultural creativity industry and develop sports cultural creativity products with competitive advantage, so that its market competitiveness will be improved. Overall, if the sports industry wants to have better and healthier development, it must combine with other industries and technology, innovation is needed on the basis of the original to create new development forms and new industrial structure [6].

(3) Sports cultural creativity industry has the question of evaluation system. Sports cultural creativity industry as a relatively independent industry have not been recognized by people on the concept, created value in practice is often harmony with the sports industry together, created economy benefits have not included in the scope of national statistics formally, so it lacks of scientific evaluation system. Therefore, output of sports cultural creativity industry only has "price" and can't be defined an exact "value". So far, China has not yet put the sports cultural creativity industry into the scope of statistics and indicators accounting system formally, there is no clear division. Different areas have different criteria for the classification, which result the confusion of criteria in sports cultural creativity industry, it is bound to bring some influence to China's sports cultural creativity development and exchanges in various areas, and is not conducive to the development of sports cultural creativity industry. Therefore, our sports cultural creativity industry needs unified classification to ensure classification clarity and don't blindly seek too much, while according to regional characteristics, identifying their own development priorities respectively to seek targeted.

(4) High-end talents are severely lacking. Sports cultural creativity industry needs to high gather high-end talents, all developed creative ideas and intellectual property and others need talents to complete, and because of its relatively backward development awareness, many people still do not realize its importance, so they do not choose this job. Sports cultural creativity industry is essentially content industry, so content is the core competitiveness, as a new industry, sports cultural creativity industry requires a lot of innovative talents. Data show that in New York, talents in sports cultural creativity industry account for $12 \%$ of the working population, and it is $14 \%$ in London and is $15 \%$ in Tokyo, while the proportion is relatively low in China, which became a stumbling block to the development of sports cultural creativity industry and constituted a major obstacle to the development [7]. 


\section{The Countermeasures of Development of Sports Cultural Creativity Industry}

As mentioned above, aimed at the problems existing in the development of sports cultural creativity industry, specific measures and countermeasures are put forward depended on the specific circumstances.

(1) Focusing on the promotion of the internal structure of sports cultural creativity industry to create reasonable industrial layout benefited to investment development. Development of sports services is a top priority of development strategy of China's sports cultural creativity industry in the new century, and only developing sports services, so that China's sports cultural creativity industry structure can be optimized effectively to achieve sustainable development of sports cultural creativity industry. Secondly, promoting the higher and tighter integration of cultural creativity industry and sports industry to enhance overall competitiveness and promote the transformation and upgrading of the sports industry.

(2) The government needs to do development plans of sports cultural creativity industry and vigorously support sports cultural creativity industry. The development of sports cultural creativity industry needs the macro-regulation of government. Government' targeted industrial policy, strategic planning and action plan is the key to highly develop scale and systematic creativity industry [8]. The government must to do the development plan creativity industry and to increase efforts to support and guide the investment and financing, legal environment and institutional innovation and other aspects, so as to promote the sustained, rapid and healthy development of sports cultural creativity industry. For example, in the credit aspect, some concessions of interest rates are given for enterprises within the national floating range of lending rates. On the land permission of sports cultural creativity industrial parks, the government should support major and important sports creativity enterprises and land demand of projects, optimize and simplify approval procedures of land application.

(3) Resources should be adequate and reasonable used to promote health and sustainable development of sports cultural creativity industry. Sports cultural resources must integrate all forces to scientific plan, rational plan and form distinctive cultural products, and the market will accept it and efficiency can be achieved. After the formation of industrial scale, it needs to do the maintenance of industrial resources market, update of content form and reasonable marketing of products to make it healthy, complete and sustainable develop.

(4) Introducing and training talents of sports cultural creativity industry, and creating development environment for outstanding talents. Training the talents of sports cultural creativity industry is the inevitable choice to speed up the development of sports cultural creativity industry. Therefore, we should strive to cultivate complex creative talents, they understand business and management of sports industry with profound cultural knowledge, and they have innovative thinking and good at discovering and solving problems [9]. To achieve this goal, we must first create a favorable living environment that they can play talents, the training mechanisms and training bases should be established. In addition, it is important to strengthen personnel exchanges and cooperation with foreign countries.

(5) The experiences of sports cultural creativity industry in developed countries need to be learned. Currently, experts have a certain basis on theory, but the systematic study for the industrial layout, policy development, talents resources of abroad creativity industry development is still a blank. Therefore, it is necessary to learn, understand and master the strategies, experiences, lessons, methods and outstanding achievements from developed countries, and digest and absorb them.

\section{Conclusion}

Sports cultural creativity industry is an important part to achieve long-term interests of the sports industry and overall development. Development of sports cultural creativity industry is not only an important factor to drive overall economic development of a harmonious society, but also an important guarantee to promote sports resources optimization and enhance the overall strength. 
However, the current actual situation is that creativity and culture are just floating in the water, its success stories of in-depth analysis it to make it be industrial development form are rare. In this paper, the development of sports cultural creativity industry was analyzed in order to be able to awaken people to pay attention to sports cultural creativity industry. And in-depth analysis the causes of development problems and seek effective solutions to fully release sports cultural creativity industry to promote it rapid develop.

\section{Acknowledgement}

This work is supported by social science fund project of Liaoning province (L14BTY002): Development Strategy Research on "cultural strong province" under the perspective of Liaoning sports cultural creative industry.

\section{References}

[1] C. Y. Liu, "Suggestions for miao nationality traditional sports cultural creative development research," Master's degree of Jishou University, 2014.

[2] W. Zhou, "A study on sports cultural creative industry of China," Master's degree of Shenyang Sport University, 2010.

[3] Y. Yu, "Analysis of the development of sports culture creative industry," Sichuan Sports Science, vol. 33, no. 1, pp. 7-9, 2014.

[4] B. Yin, X. Feng, "Study of the sport cultural creative idea industry in Beijing," Journal of Physical Education, vol. 17, no. 6, pp. 21-24, 2010.

[5] Y. Liu, "Study of sports culture creative industry's value and development in China," Bulletin of Sport Science \& Technology, vol. 20, no. 3, pp. 24-25, 2013.

[6] F. Long, "The study of the sports cultural creative industry in Henan province," Master's degree of Henan Normal University, 2013.

[7] K. Nan, "The exploitation and development of sports culture creative industries in Shandong," Journal of Jilin Institute of Physical Education, vol. 28, no. 1, pp. 44-47, 2012.

[8] W. L. Yang, X. P. Kang, "Countermeasure study of speeding up the development of sports culture creative industries for Northern Lake City," Contemporary Sports Technology, vol. 2, no. 36, pp. 98-99, 2012.

[9] W. B. Xue, B. Weng, W. Liao, "The conception of developing creative sports industry in Fujian province," Sports Science Research, vol. 18, no. 6, pp. 37-41, 2014. 